\title{
Liter per Nanomole per Hour
}

National Cancer Institute

\section{Source}

National Cancer Institute. Liter per Nanomole per Hour. NCI Thesaurus. Code C85690.

Liters per nanomole per hour. 